FACTA UNIVERSITATIS

Series: Philosophy, Sociology, Psychology and History Vol. 15, No 3, 2016, pp. 103 - 118

DOI: 10.22190/FUPSPH1603103C

\title{
FEMALE MONASTICISM IN THE BORDER LINE (Monastery of Saint Archangel Michael - Berovo)
}

UDC 271.2-788-055.2(497.17)

\section{Ružica Cacanoska}

\author{
Ss. Cyril and Methodius University, Skopje, R. Macedonia
}

\begin{abstract}
The subject matter of this paper is a review of the key moments of the foundation and daily life at the female monastery within the church St. Archangel Michael in Berovo. The female monastic life in the monastery is an activity which has been taking place continuously for more than one and a half century. The religious services in this monastery besides the nuns from Berovo are attended by the nuns from the monastery of Veljusa. The monastery is open for visitors. They can also use the library of the monastery, which keeps the memory of enlightening work of Joakim Krchovski, the founder of the first cell school. Life in the monastery takes place following the hesychastic typikon (svetogorski), although it has an urban location and it is much visited. The monastery functions as an intensive hesychasm, hesychasterion. Inside the church, there is a small chapel dedicated to St. Gregory Palamas and Elder Joseph the Hesychast. Religious services and liturgies are held every day in the monastery. The monastery is headed by an abbess. The functioning of the monastery is organized by duties, which are called obediences. The specific characteristic of this monastery is the preparation of food products which are traditional for this region, as well as the creation of mosaics. Although MOC - OA is not recognized by the orthodox churches throughout the world, the nuns at this monastery have frequent communication with the nuns who are not from their immediate vicinity, but from Romania and Greece.
\end{abstract}

Key words: monastery, female monasticism, border line, typikon, religious tourism.

Received July 8, 2016 / Accepted July 24, 2016

Corresponding author: Ružica Cacanoska

Ss. Cyril and Methodius University, blvd. Goce Delcev 9, 1000 Skopje, R. Macedonia

E-mail: ruzica-c@hotmail.com 


\title{
1. INSTEAD OF AN INTRODUCTION - A MONASTERY ON THE BORDER LINE
}

\begin{abstract}
I stand at the middle of the church and I can feel all those painful souls more than I can think about them ... and I am sure that they are as close to me as far as they are from my time, and I know they are inviolable, as all similar ones, which left the body, which remained to live outside it. I also try to prove through the word of the nun, whose lean face confirms me that no lesson can be extracted without suffering ... It seems that her face reflects the entire past of the monastery...
\end{abstract}

Faithless Year - Petre M. Andreevski

The female monastery of St. Archangel Michael is located in the border line between the Republic of Macedonia and the Republic of Bulgaria. In fact, the eastern part of the municipality of Berovo, in which the central urban core of the monastery is situated follows the border with the Republic of Bulgaria.

The border between the two countries is only fifteen kilometers away. It is near the border crossing Klepalo, which is built on the Macedonian part, while it should finish on the Bulgarian part. With the revival of that border crossing the level of the border cooperation would be improved allowing further resources for communication and cooperation in the field of the spiritual life.

This valuable cultural and historical monument is situated at the exit from the town of Berovo, on the road to Berovo Lake and the dam. The main gate of the monastery is facing the city and the other two gates are facing the river and the dam. By entering through the wooden door of the monastery complex, the visitor steps into a "perfect oasis of peace and spiritual grace". ${ }^{1}$

The dense pine, beech and oak forests, meadows, the richness of flora and fauna, unpolluted natural ecosystems, biodiversity composed of endemic species, healing herbs, berries and mushrooms, healthy food known for widely famous traditional agricultural products, among other things, contributed to the epithet "Macedonian Switzerland". Berovo is a rare worldwide phenomenon and widely known for the highest concentration of oxygen in the Balkans. Namely, through this area passes one of the four world corridors, which contain large amounts of oxygen, which contributes to creating the ideal conditions for the development of air spa tourism. The citizens of Berovo live at an altitude of 800 meters above sea level and are particularly proud of its serenity and the chilly climate present during the whole year. In folklore, the beauty of this region is mentioned in songs through the verses "from three sides the sun shines, from the fourth side the moon shines".

\footnotetext{
${ }^{1}$ These words were written by a visitor in an interview during her visit to the monastery (which is then transferred to an interview with visitors of the monastery).

${ }^{2}$ MIA, Macedonia for Beginners - From Three Sides Sun Shines, 14. 1. 2014,

http://www.mia.mk/mk/Inside/RenderSingleNews/254/132150857, visited on 08.04.2016.
} 
What makes up the idiosyncrasy of Berovo is that it is one of the few cities with a monastery in its center. The rich carved ceilings, beautiful polygonal picturesque bell tower, the church yard, legends, stories and behests that are hidden behind the walls of the monastery, are the words with which the citizens of Berovo start their conversation about the monastery of St. Archangel Michael.

The monastery belongs to the Strumica diocese and since 1995, the monk Nahum was consecrated into Bishop of Strumica, after he returned from the Gregoriou monastery on Mount Athos.

In general, the importance of the monastery is confirmed by the fact that it was at the center of numerous events from the near and distant history of this region. Of course, prominent figures from this region are also directly or indirectly connected with this monastery. Thus, we can talk about the educational activities of Joakim Krchovski, about the cell school, about the preserved memories and rare books, which are part of the library core of the monastery. Historical records about the monastery on the border line also speak about the influence exerted by the Greek, Bulgarian and Serbian Churches.

\section{THE HISTORY OF THE MONASTERY}

The connoisseurs of the religious situation in the Macedonian country indicate the strong commitment of the population to the orthodox Christian doctrine and throughout the Bregalnica region. Historical records mention that at the beginning of the nineteenth century, during the Ottoman rule, "in Berovo citizens appeared a providence and desire to create a place where they could express their love and faith to God in a dignified way" (Panajotov 2012, 13). In that period Berovo was a rural settlement, which consisted of about two hundred houses. In that rural settlement there was "only a small and dilapidated church." 3 The most prominent citizens of Berovo ${ }^{4}$ agreed to build a new church in the neighborhood called Mogila. But in order to build it, they needed to provide permission from the Turkish governor (Vali) of Radovish. The Vali conditioned his permission with several extremely difficult, almost impossible to realize demands. The church was to be built below the road level and it should not be seen by the passengers. At the same time the church was to be built for only forty days and the third condition was that the parish priest Peco had to give his youngest and most beautiful daughter Sultana to the Vali's harem. The citizens of Berovo accepted those seemingly impossible conditions. And they all gathered, young and old, put their greatest efforts working around the clock, and they managed to build the church and to cover it with wooden boards. On the fortieth day, the Vali came to Berovo to see the construction, and at the same time, with trumpets and drums to take Sultana to his harem.

According to some stories, it is said that due to the fact that all demands regarding the construction of the church were not completely fulfilled, in order to hide the external wall of the church the citizens of Berovo decided to cover it with soot and lime. When Vali noticed that, he ordered the execution of the three church elders in front of the church,

\footnotetext{
${ }^{3}$ MPC-OA, Berovo - Monastery of the Holy Archangel Michael, http://www.mpc.org.mk/mpc/se/berovo.asp, visited on 05. 03. 2016.

${ }^{4}$ As a ktetor of the church is mentioned the priest Peco.
} 
and the imprisonment of the priest Peco because his daughter Sultana fled to Kjustendil. The priest was kept in prison for three years. After his daughter Sultana learned that the Vali had been killed, she returned to Berovo and got married here. But, according to another story, on her way to the harem, Sultana jumped from the horseback into the waters of the Dojran Lake. The soldiers in the convoy thought that she had drowned and they continued the journey without her. But she hid for ninety days in one shepherd's hut. When she learned about the death of Vali, she returned to Berovo and became a nun. It is said, according to this story, that she was actually the first nun in the monastery of St. Archangel. She founded the sisterhood and was named Eugenia. The building of the church was completed in 1818. This year is written on the west entrance door of the church in Slavic language and Arabic numerals: "The year of our Lord, 1818".

The monastery church has three naves, a large porch and it was built according to the architectural traditions of the $19^{\text {th }}$ century. The style of the church construction, the wide verandas and dormitories built of stone, carries the features of authentic Macedonian architecture from the $19^{\text {th }}$ century. A special beauty lies in the skillful craftwork of the wooden ceilings and especially of the central nave and the female part. ${ }^{5}$ The citizens of Berovo specifically emphasize the work of the Macedonian woodcarvers who have skillfully produced the wooden ceilings, ${ }^{6}$ verandas, the wooden pillars of the open porch of the church, the windows, doors and the fence, as well as the monuments in the monastery which reflect the rich history of the region of Maleshevo.

The images of the saints inside the church are painted in a characteristic style which deviates from the adopted Byzantine canons. The iconostases which capture with their beauty are the work of the famous woodcarvers: Acko Arnautov, Atanas Sokolov and Kosta Pavlov.

"Only one icon representing the Holy Prophet Noah is preserved from the original iconostasis, which was made in 1818 by the painter George Veljanov from Strumica. From 1899 to 1920 the painter Gavril Atanasov - Berovec was also working in this monastery. The main, central icon of the Assumption of Mary is the work of the painter Gregory Pecanov from Strumica, painted in 1887.".8

The monastery complex is, of course, dominated by the church with its large porch, made of massive oak pillars. The iconostasis which separates the altar from the central part of the church is composed of 10 so-called royal icons which represent artistic master pieces. ${ }^{9}$ The dormitories of the monastery, built on the southern, western and northern sides of the church reflect the old Maleshevo architecture. The church is furnished with appropriate church furniture from the $19^{\text {th }}$ century.

\footnotetext{
${ }^{5}$ Makedonsko sonce, Macedonian centuries' long spiritual existence, Exclusive feuilleton, prepared by Mileva Lazova, The Legend about the Berovo Monastery, 637/2006, visited on 2. 3. 2016, p. 33.

${ }^{6}$ Special beauty is hidden in the skillful craftwork of the wooden ceilings and especially of the central nave and the female part.

${ }^{7}$ Downloaded by http://loza.mk/2015/09/ubavinite-na-berovo-foto-galerija/, visited on March 27, 2016.

${ }^{8}$ Downloaded by http://www.mpc.org.mk/mpc/se/berovo.asp, visited on March 21, 2016.

${ }^{9}$ Center for Development of East Planning Region, Ilieva-Arsova V., Work group, 2011, Pijanec-Malesh, Abundance of Sun and Smiles, https://issuu.com/eastregionmk/docs/pijanec_i_males.pdf, p. 29.
} 
The dormitories have an irregular shape and they consist of 16 rooms or, a total area of $560 \mathrm{~m}^{2}$. The monastery abounds with many surfaces made of wood, with ornaments which reflect the old style from the architectural traditions of the $19^{\text {th }}$ century.

\subsection{Again about the female sisterhood}

The foundations of the female monastery were laid around 1840 or approximately twenty years after the completion of the monastery church. Two heirs of the family of the older sister of Sultana became nuns in 1848. According to the monastery records, from then until today, the female monastic life in this monastery did not fade at any moment. According to the records of the historical events, the first nuns at the monastery were the daughter-in-law and the daughter of Father Risto, who was the son-in-law of the already mentioned parish priest, Father Peco. They received the blessing for becoming nuns by the abbot of the Rila Monastery. They started their life in the monastery living in two rooms next to the church. A little girl lived with those two nuns. The first abbess of the monastery was Eugenia I, ${ }^{10}$ the second was Eugenia II, the third was Eugenia III, and the fourth abbess was Eulampia. She was promoted into the rank of abbess in 1958 by the first Archbishop of Ohrid and Macedonia HH Dositheus.

The Berovo monastery is connected with two extremely important and striking personalities in the history of this region, Dedo Iljo Maleshevski and Dimitar Pop Georgiev from Berovo. Dedo Iljo is also connected with the creation of the female monastic community. Namely, Dedo Iljo Maleshevski was a popular outlaw who fought against the Turks. In order to protect him, the priests of this church, as well as most of the citizens of Berovo, initiated the establishment of the female monastic community.

"For that purpose they persuaded the widow Dona, Father Peco's daughter-in-law with her underage daughter Lisaveta. The first nun received her rank at the Rila Monastery. She was made a nun in 1850 . The year of 1850 is considered to be the birthday of the monastery female sisterhood (Teoharov 2004, 18-19)."

Following the establishment of the sisterhood, many widows and unmarried girls from all populated places in Maleshevo region and beyond (from Kochai, the Strumica area etc.) found their place in it. The number of the members of the community was growing and soon the first cell school was established there. As the number of nuns in the sisterhood was increasing, the property and goods which they possessed was also increasing. Soon after there appeared the need of mountain methocian which was organized in the settlement Turtle - Babine kilobit. Thus developed monastery and the organized methocian had a particularly important role in the revolutionary days which followed and which were extremely important for the Macedonian nation. Those events were the Razlovtsi Uprising (1876) and Kresna Uprising (1878). For the needs of the Razlovtsi Uprising, Dimitar Berovski decided to sell all his property in Berovo to the monastery of St. Archangel Michael (Trajanovski 1990, 84). The uprising was organized

\footnotetext{
${ }^{10}$ But, according to another story, on her way to the harem, Sultana jumped from the horseback into the waters of the Dojran Lake. The soldiers in the convoy thought that she was drowned and they continued the journey without her. But she hid for ninety days in one shepherd's hut. When she learnt about the death of Vali, she returned to Berovo and became a nun. It is said, according to this story, that she was actually the first nun in the monastery of St. Archangel. She actually founded the sisterhood and was named Eugenia.
} 
by Father Peco's grandson, Dimitar Pop Georgiev Berovski ${ }^{11}$ who was also a teacher at the church cell school which was later a part of the monastery complex. In that period the abbess of the monastery was his aunt Eugenia. The money collected from the sale was used to provide the necessary equipment for the uprising. According to the records of Teoharov, the nuns had an important role in the activities related to the uprising. They served as couriers between the organizers of the uprising who were at different locations. Even the agile Turkish authorities could not discover their activities.

The Greek bishop was also expelled from the monastery of St. Archangel Michael. A large number of distinguished citizens of Berovo were imprisoned. According to the historical documents, part of the population was "subjected to torture in the place of the uprising - the monastery courtyard" (Teoharov 2004, 20). ${ }^{12}$ Soon after the Turkish authorities, while listening to the song of the nun Agnina which glorified the "banditry" of the Maleshevo people, suspected that there was a connection between the female sisterhood and the organized resistance of the Berovo people against the Greek bishop. They searched the entire monastery and burnt "all the books and archival materials" (Teoharov 2004, 20). At that time the handwritten materials of Joakim Krchovski, as well as the books in the monastery library were burned.

Shortly after this event, the Razlovtsi Uprising broke out, which was suppressed by the Turkish authorities. Then followed a series of activities related to the Kresna Uprising. The monastery even took part in the Ilinden Uprising. The two interviewed older Berovo citizens proudly speak about the important role of this monastery during the National Liberation War, as well. The longtime priest in this monastery and good connoisseur of the history of this region, Teoharov Ahil recorded:

"And when the Maleshevo pretty villages were burnt and destroyed by the fascist occupier, the monastery offered shelter to many mothers with their young children and young girls who wore nun's cloths until the horrible threat was over (Teoharov 2004, 21)."13

In the monastery of St. Archangel Michael, His Eminence Nahum, the Bishop of Zletovo and Strumica sanctified the first holy antiminses, issued by the diocese of Zletovo and Strumica.

This Monastery is also linked to the emergence of the so-called white monks. Namely, the longtime abbess of this monastery, Sister Macrina, a few years ago receded from the monastery. Soon after that, sister Sinklitikija was appointed the abbess of the monastery, who initiated the production of the widely famous mosaics.

\footnotetext{
${ }^{11}$ Son of Father Gjorgji Dimitriev. Dimitar Berovski was also prepared to become a priest, according to the family tradition, and for that purpose he was sent to get educated at the Odessa Theological Seminary. Due to his beliefs, he left the seminary. He continued his education at the Belgrade Military School, and then got a job with the Serbian Army. After he has completed his education he returned to Berovo.

${ }^{12}$ The aggregated anger due to the Turkish rule and the Greek influence, in the context of the preparatory activities for the uprising, the population of Berovo gathered around the monastery, but they did not entered until the Greek bishop left the monastery. This event was the reason for undertaking many punitive measures against the population of Berovo. ${ }^{13}$ Pachemska Petreska, D., Maleshevo region through the history 1912-1945 (volume two), Berovo 2003; Trajanovski A. Church-Educational municipalities in Macedonia, Institute of National History, Skopje 1988; Angelovska-Panova, M. Monasticism in the Spiritual - historical Continuity of Macedonia, Spektar, XXIX/57, Skopje, 2011; Contributions from the scientific convention with international participation held on May 6 and 7, 2000 in Berovo, The Voivode Iljo Markov - Maleshevski and his time, Berovo 2002.
} 
Sister Michaela, who has devoted several decades of her life to this monastery, in a television interview ${ }^{14}$ spoke about the monastery as a work of the famous figure from Maleshevo region, Dedo Iljo Maleshevski, as a place where her rich spiritual and revolutionary past intertwine. At that time, as the monastery is commonly called the Maleshevo pride, in its church there is the only icon featuring the grandfather Noah and the icon where the word Macedonian is for the first time written as a signature of the author. It is the work of iconographer Gavril Atanasov, who in the period from 1899 to 1920 produced about thirty icons in the monastery. ${ }^{15}$ On the altar door of the monastery, on a tin he painted the icon "St. John Chrysostom" (1897), which represents its southern altar door. In the lower right corner he signed the work with the words: Iconographer Gavril Atanasov Macedonian from the village of Berovo, Malesh, 1897“.

The monastery complex consisting of the church, dormitories, the museum or the gallery segment of mosaics (former school, the memorial house of Dedo Iljo) as a whole represents the most valuable cultural and historical monument of the 19th century. The 72 icons of the 19th century, the specific architecture, the vivid cultural heritage are just a small part of what makes the monastery St. Archangel Michael the most visited sacred object in Berovo. Also, in the courtyard of the monastery many cultural and artistic events (book launches, art exhibitions) are organized, and a part of the legacy of the more prominent figures in the Maleshevo region is kept there. In the last two years certain conservatory works and reconstruction of the roof and the dormitories have been performed, which will improve its "condition" and contribute to its enhanced presentation and promotion.

In the courtyard of the monastery, there are crosses which mark the places where some of the teachers in the cell school were buried. There is a monument dedicated to the nuns who were buried in the monastery complex, with their photographs and names. ${ }^{16}$

\subsection{Life in the female monastery}

Since its foundation monastic life in this monastery has run uninterruptedly. ${ }^{17}$ This tradition of female monastic life at St. Archangel Michael in Berovo has lasted for more than one and a half century. There were times when this monastery was served by up to sixty nuns. ${ }^{18}$ It had its apogee at a time after decades of its long existence, that is, in the first half of the twentieth century.

It is a fact that this monastery was of great importance for this region. There are records that during the turbulent history of this region it was developed on solid economic ground, it had its own weaving mill, its theological seminary. The great impact of this monastery on the social life in this region is confirmed by the fact that the first single-

\footnotetext{
${ }^{14}$ Video material titled The Monastery of Dedo Iljo Maleshevski silently collapses, prepared by TV Kanal 5 , broadcasted on October 10, 2010, downloaded from https://www.youtube.com/watch?v=R2FIOQ4mlmA, (visited on April 15, 2016).

${ }^{15}$ Video material downloaded from http://maleshevo.blogspot.mk/2008/07/blog-post_7141.html (visited on April 27, 2016).

${ }^{16}$ At the cemetery within the monastery complex were buried widows, female novices etc.

${ }^{17}$ Downloaded from http://grid.mk/read/news/511354285/10752186/nashe-a-svetsko-najstariot-zhenski-manastirsv-arhangel-mihail-berovo, (visited on April 5, 2016).

${ }^{18}$ Some materials also mention the number of eighty nuns.
} 
phase hydro-power plant in this area was in the monastery. The history of the monastery is closely linked to the most significant historical events of the nineteenth century in the Maleshevo region, which are the Razlovtsi Uprising (1876) and Kresna Uprising (1878).

On the occasion of the consecration of the church (1818) the Macedonian leader of the national revival Joakim Krchovski was also present. Later he founded the first church cell school. The school existed until 1892, and it was attended by a number of Macedonian teachers and priests. This school has its own library, in which many books and texts from the XIX and XX century are preserved to this day and they can be also utilized for the education of many generations to come.

The historical facts about the course of history of the monastery say that the monastery offered shelter to many Macedonian fighters who were persecuted by Turkish authorities. Dedo Iljo Maleshevski and his comrades stayed in the monastery for a certain period of time. The revolutionary leader of the Razlovtsi and Kresna Uprisings Dimitar Pop Georgiev Berovski also lived in the monastery. ${ }^{19}$ All these activities that directly or indirectly relate to the Berovo monastery have become a symbol of the Macedonian identity and the struggle for freedom in the region. ${ }^{20}$

Besides the library, the monastery has a museum, in which important photos, documents, geographic maps and old weapons are exhibited, which describe the rich history of the Maleshevo region. This monastery complex has its own garden, within which are hidden four pits, which in the middle ages were used for storing grain (barns). The pits were discovered during the leveling of the terrain around the monastery in 1974 (Grozdanov 1996).

Today the monastery opens its doors wide for each visitor who "steps over the monastery threshold, thus entering God's Rooms on the Earth in order to find its serenity..." ${ }^{21}$ The monastery is open for visitors every day during the week, with a number of activities within it, where the special personal engagement of the sisterhood gives a special impetus to the life of the monastery. Probably in this context the individual approach to each visitor should also be considered, since they have crossed the threshold often looking for spiritual peace, tranquility and understanding, sometimes due to his curiosity, and sometimes due to his pain.

In the past there was an active icon painting school within this monastery. Monks from this monastery made icons in the Byzantine style. It is also linked to the restoration of the fresco painting in the Macedonian monasteries.

Life in the monastery takes place on hesychastic typikon, although it has an urban location and it is much visited (svetogorski). The hesychasm in Macedonia was characteristic in the $14^{\text {th }}$ century. But, today it is restored and applied more due to the Mount Athos monastic life of the part of the Macedonian bishops. The typikon was introduced in the largest monastic communities in Macedonia, in the monastery St. Jovan Bigorski.

Inside the church a small chapel dedicated to St. Gregory Palamas and Elder Joseph the Hesychast has been built. This chapel was completed and the frescos painted ${ }^{22}$ in 2014

\footnotetext{
${ }^{19}$ The documentary film dedicated to Dimitar Pop-Georgiev Berovski, filmed... begins with feature scenes, filmed in the monastery, in 2014, with the nuns Mihaela and Macrina.

${ }^{20}$ Tanevski, Gj. 2015, a document titled St. Archangel Michael.

${ }^{21}$ Written by an older Berovo woman in her e-interview (conducted during the collection of empirical evidence for this work).

${ }^{22}$ The iconostasis and the main central icons in the chapel were made by the icon painter and woodcarver Vancho Chaushevski.
} 
with the donations of well-intended visitors. It serves as a winter church. In fact, due to extremely low temperatures which are typical for this region, for the largest period of the year precisely this chapel is used for services and liturgies.

There are services and liturgies every day in the monastery. The monastery is headed by an abbess. The functioning of the monastery is organized by duties, which are called obediences.

Trying to explain her role in the monastery abbess Sinklitikija says:

\begin{abstract}
"In essence, our meeting with any person in our life is a test of our love for God. We have abundance of Love of God in every moment of our existence, regardless of how much we are aware of it or not. The only problem of our lives is how to give back that love, as to love for all people and we need to decide that we will give them love without asking them, thus providing us with a certain degree with tranquility. Celebrate this as a challenge, as the ultimate witness to Christ in this world to love one who makes harm to me." - The nun conveys the thought of her spiritual father, Metropolitan Nahum.
\end{abstract}

Often, some residents of Berovo and frequent visitors of the monastery, emphasize precisely the openness, honesty and, certainly, good faith of the nuns who live there. Abbess Sinklitikija states that her obedience is to treat the visitors of the monastery with great hospitality. But, she continued pointing out that "people usually come to church when they feel joyful or have some trouble, that is, after they realize that everything depends on God"“ ${ }^{23}$ She listens to them and tries in good faith to give them some advice, and to help them.

Older residents of Berovo still remember the great wealth which was possessed by the monastery, expressed in large land holdings and, certainly, in the large number of livestock and agricultural machinery. But during the war high taxes imposed on land, especially agricultural land, which forced the church authorities to begin to "donate the land", where a part of that land was indeed confiscated by the state. The atheistic ideological framework of the newly created Macedonian state was not in favor of the recruitment of new generations of nuns, which led to the decrease of the number of nuns in the monastery.

It is not a coincidence that the museum rooms dedicated to the Razlovtsi and Kresna Uprisings, as well as the bust of Dedo Iljo Maleshevski are set in the monastery complex. In the period after World War II or during the period of communism, the monastery functioned as a museum. In an interview, Sister Macrena talks about the period when she joined the monastery:

\begin{abstract}
When we came to the monastery in 2000 , we took out the museum exhibits which were displayed in the rooms of the dormitory. There was a happy circumstance that people who at that time worked as curators had an office in the monastery dormitories, and had a great understanding for our arrival and took us ahead, helping us to arrange more or less the space for normal living. However, the fact that the monastery was perceived as a museum for a full 50 years has left traces. Even today there are moments when people (of course not all) see us as a part of the museum's exhibits. ${ }^{24}$
\end{abstract}

\footnotetext{
${ }^{23}$ Zarevska, R., A man is welcomed only in good faith, Nova Makedonija, on-line edition, 22935, 23. 7. 2013, http://novamakedonija.com.mk/NewsDetal.asp?vest=72313853588\&id=9\&setIzdanie=22935, visited on 5. 4. 2016.

${ }^{24}$ An interview published on the portal Premin, The Monastery "Saint Archangel Michael" in Berovo Left to the Ravages of Time, published on May 28, 2008, http://preminportal.com.mk/duhovnost-2/intervju/1951manastirot-sveti-arhangel-mihail-vo-berovo-prepushten-na-zabot-na-vremeto, visited on 11.02.2016.
} 
The monastery St. Archangel Michael as a cultural monument may receive some assistance for its maintenance, ${ }^{25}$ but its other needs should be supported by revenues from its own economy or from the contributions of believers or visitors. In order to obtain this revenue, the nuns make very delicious jelly from wild strawberries and cheeses with various specific spices which they sell. In addition, they offer a large variety of religious items made by hand, whose sale supports the organization of their life in the monastery. They also make mosaics in this monastery and have their own gallery where the work is exhibited and available to the visitors.

\section{METHOdOLOGICAL FRAMEWORK OF THE PAPER}

This paper is grounded on a large variety of secondary data sources (books, historical records, data on Berovo and the monastery obtained from several Internet sites).

At the same time, an empirical database (primary base) was provided for the preparation of this paper. This database was collected by using a qualitative methodology or through semi-structured interviews and face-to-face interviews. The sample was focused and it consisted of 10 current or former citizens of Berovo who have at least several visited the monastery and are at least familiar with its history. Through these interviews I will make an effort to outline the perception of those persons regarding the life and, certainly, the influence of the monastery on the life of its environment, that is, region.

Out of the 10 interviews, 7 were e-interviews, while 3 were face-to-face interviews. Four interviewees were over 65 years of age, while the rest ranged between 24 to 57 years. Because the elderly are not familiar enough with computer technology, their interviews were made by assistance of their grandchildren. Within that group of 10 interviewed people, 6 were men and 4 were women. The 10 interviewees were guaranteed anonymity.

In the course of writing this paper, I conducted a separate e-interview with the abbess of the monastery Sister Sinklitikija. ${ }^{26}$ At the same time, e-interviews were conducted with all the nuns, that is, novices who were currently staying / living in the monastery.

It means that we conducted 15 interviews in total. All the interviewees were informed of the goal, purpose, method of analysis and use of the data. These interviews were conducted after we received the consent of the future interviewees.

The 10 interviewees, as well as the four interviewed nuns, that is, novices, were guaranteed anonymity.

The basis of the interview was made according to the key research questions, but with certain differences which were specific for the group or the persons being interviewed.

\footnotetext{
${ }^{25}$ Its maintenance is made more expensive and difficult because the church is built under ground which allows the moisture of the soil to penetrate into it and to spread to the upper parts of the church. In 2015 the Ministry of Culture of the Republic of Macedonia undertook a number of activities for the preservation of the church and the other auxiliary premises of the monastery complex.

${ }^{26}$ Sister Sinklitikija was interviewed twice, once in the capacity of a nun, and the second time in a capacity of the abbess of the monastery. The photographs which are included as illustrations of this paper are predominantly made by Father Teofil. These photographs were sent to me by the abbess of the monastery sister Sinklitikija.
} 


\subsection{Key research questions:}

1. How does the permanent monastic life in the monastery take and how did it take place?

2. What are the main features of this monastery and the female monasticism therein?

3. In which way does the female monastery operate today? (Description of a typical day in the monastery and the main challenges the nuns face)

4. In which way were the nuns in the monastery recruited in the past, compared to nowadays?

5. Do they communicate with the nuns from other monasteries? Do they interact with the nuns from Bulgaria, especially those who are near Berovo (near the border line)?

When analyzing the qualitative empirical basis, certain issues are synthesized, they are displayed as synthetic indicators while other "points" of the answers of the interviewees can be mentioned in the original format (as expressed or recorded) .

The draft study is cross-sectional (Bryman 2012) with a longitudinal dimension, which is primarily incorporated through the secondary base of historical facts.

\section{THE MONASTIC LIFE IN THE MONASTERY - THEN AND NOW}

Based on the analysis of the collected empirical material (the answers of the interviewed residents of Berovo or persons originating from the town, who now live in another city or populated place), the interview with the abbess of the Monastery St. Archangel Michael and nuns and novices who live in the monastery, as well as the secondary database, I will elaborate the pre-set key research questions. It will follow the already established order of questions.

\subsection{How does the permanent monastic life in the monastery take and how did it take place?}

Numerous historical records, articles in the media, and empirical data collected for this paper suggest that in the Berovo monastery St. Archangel Michael, since the monastic vows of Eugenia, in the distant 1848 until today monastic life has existed continuously. The female monastic life in the Berovo monastery with almost two centuries of tradition is an observer of the social life in Maleshevo region and its annalist.

An elderly resident of Berovo in the interview said that his mother had a sister who was a nun. He says that from his childhood he remembered the words of his mother, that her sister told stories that behind the monastery gate a special spirit directed the whole life in the monastery. "It is an invisible force which assists the nuns to perform with ease both the heaviest and the lightest monastic obediences"; one younger respondent conveys the experience of some novices and nuns from the monastery.

Another older resident of Berovo indicated that in the periods when the monastery counted hundreds of nuns and novices, the monastery as a huge economic unit just could not survive without strict adherence to the rules. He also explains, recalling the words of his ancestors, that the monastery as such has often been a shelter and sometimes a dream for the hungry, sick and exhausted residents of this region. But, the same respondent explains in his face to face interview that the strict rules which regulated the life in the monastery had to be obeyed by everybody. 
The monastery used to have its own order and life in it as a "holy" community, the periods of crisis were especially far easier. "In the monastery I found my tranquility and the meaning of my life," another female resident of Berovo wrote in her e-interview about her distant cousin who became a nun there.

"Life in the monastery is led by the prayer and dedication to God," a younger resident of Berovo who has visited the monastery only a few times (even though it is near his home), wrote in his e-interview. He learned about the monastery through watching videos online and recognized the dormitories which were featured in those video materials. He says that his grandfather's sister had a great desire to become a nun, but his family forbade her to do it. ${ }^{27}$ The interviewee said that his grandfather's sister got married far away from Berovo and that they did not respect her last wish to take her to the monastery before she died. Therefore, he continued, I think that the monastery has a special power which is reflected in the tranquility which can be also felt outside the monastery gates.

"In every corner of the monastery you can feel the rich history of the Maleshevo region" wrote another interviewee. He especially emphasized the responsiveness and the openness of the nuns who are always ready to answer the numerous questions asked by all visitors. He also said that the nuns without exception were willing to help each of them who asked for help, both in the past and now. According to historical legends about the monastery, another interviewee wrote a long answer about the role of the monastery in the history of the Maleshevo region. "All the nuns often did not hesitate to violate certain norms imposed by the church, in order to serve their people. ... The history of the monastery and the Maleshevo region is closely connected, thus forming a whole." In a face to face interview, an older resident of Berovo explained that his great-grandfather, grandfather and grandmother, always spoke about the high morals and dedication of the nuns and novices in the monastery. His grandfather told him that when they were children that they used to stand in front of the gates of the monastery, and then the nuns often exited the walls of the monastery and offered them food. He says that they practiced it even during the worst crises, and he also recalls that one of his distant cousins, who was a nun at the monastery, regularly shared her meal with the locals, especially with children, in the most difficult periods.

Life in the monastery, in the past and today, takes place following a specified typikon. The implementation of the typikon requires the blessing of the Bishop of the diocese. In her interview, the abbess stated that each Sister had her obediences (host, treasurer, housekeeper, Sister in charge of the kitchen, maintenance of the churchyard, etc.). She says that today the main activity of the monastery is making mosaics.

Sister Sinklitikija also says that the mosaics she makes are so successful because of the prayer which she says during their manufacturing.

\footnotetext{
${ }^{27}$ In the footnote to his answer he has stated that according to his grandfather's words, there was a nun in almost each family. That is why he holds that the life in the monastery took place somehow "parallel to, or supplemented and supported the life of the population which was sometimes very difficult". It especially applies to the periods when the monastery had in its possession large asset, while the female sisterhood numbered up to 120 nuns and novices (according to the words of his grandfather).
} 


\subsection{What are the main features of this monastery and the female monasticism therein?}

Almost all the empirical materials are dominated by a fact which is characteristic of the Monastery of St. Archangel Michael, that is, the continuing female monasticism, which has lasted for almost two centuries. Since the foundation of the monastery, until today, there were always nuns present in the monastery. The nun Michaela, who devoted several decades of her life to the monastery, according to the abbess of the monastery, is a bridge between the older and younger generations of nuns. The abbess also wrote in her communication with the author of this paper that she was a contemporary of the old and the new monasticism. Therefore, she suggests that "the monastery was never ... empty."

Another significant feature which makes it different compared to other monasteries is its location in the center of the city. Commonly, the monasteries are located outside the urban areas, but here in the course of history it became a monastery located in the heart of the urban community. In her interview, a nun stated that because of the proximity of the hotel, the peace of the monastery is disturbed.

A very important feature of the monastery is the unity of the life in the monastery and the life of the residents of Berovo. "It is not a coincidence that the monastery was visited by the most important figures in the history of the Maleshevo region", said an old resident of Berovo who was also interviewed. This feature of the Monastery of St. Archangel Michael is also mentioned in the responses of almost all the respondents from Berovo. According to the words of one Berovo woman in the face-to-face interview the priest Ahil Teoharov was an annalist of his time, and particularly of the monastery life. She said that he prepared an interesting monograph on the monastery, kept minute records of all events as well as of every data in his possession.

In recent years, the monastery has become widely known for making mosaics. Mosaics made in this monastery can be found in the church of St. Petka in Strumica and the church Protection of the Holy Virgin in Shtip. At the same time, the compound part of the monastery complex is the gallery of mosaics. The mosaics in the gallery are offered for sale, and they are also made by order of the customers, explained the abbess of the monastery. They plan to share their knowledge and experience in making mosaics with those who are interested in that craft by organizing summer courses and seminars.

"The trademark of the Monastery of St. Archangel Michael are the traditional food products such as jelly, cheese, honey and the alike," replied one resident of Berovo who said that he was a regular buyer of some of these products. Four interviewees responded in a similar way.

Two interviewees emphasized that the specificity of this monastery is also the fact that the history of white monasticism in Macedonia started there. ${ }^{28}$

\footnotetext{
${ }^{28}$ Namely, sister Macrina after spending 14 years of her life as a nun, decided to leave the monastery St. Archangel Michael. One of the interviewees asked additional question about the future life of the previous sister Macrina (who now uses her secular name Budimka Popovska and works as a columnist in a Macedonian weekly newspaper) and whether it could be "regulated" by the Holy Synod of MOC-OA.
} 


\title{
4.3. In which way does the female monastery operates today? (Description of a typical day in the monastery and the main challenges the nuns face)
}

The Monastery of St. Archangel Michael has its own typikon. According to the established typikon the abbess of the monastery describes a usual day as follows:

\begin{abstract}
The day starts with synaxis (cautionary words of the Holy Fathers are read), and then the Liturgy follows. After the Liturgy is over, until the first meal the Sisters perform their duties. After the meal, the Sisters return to their everyday duties. In the afternoon we attend evening service, followed by the second meal. Then we complete our working tasks, and in the evening we read Akathist of the Virgin Mary-Compline. Then the Sisters retire to their rooms, and the monastery is closed.
\end{abstract}

All these tasks are blessed by our spiritual father and the abbess distributes them according to the needs of the monastery.

In her e-interview, another nun or novice regarding their activities stated that one Sister serves as a host; another Sister is in charge of cooking, the third one is in charge of the church yard, and the fourth Sister is in charge of making mosaics.

Usually during the summer time there are lots of tourists who visit the monastery. The hospitality and the attention which the nuns pay to the every visitor of the monastery are far known. The tourist offer related to this area devotes a lot of attention and space to this Monastery. The development of cultural, especially monastic tourism attracts a large number of local and foreign tourists. It was also noticed that the number of "those who attend the services at the monastery is increased, which indicates that people are really in need of spiritual support," says in their replies not only the abbess of the monastery, but also some of the interviewees. The visitors of the monastery, as the abbess of the monastery Sister Sinklitikija says, are requested only to respect the order of the monastery.

When analyzing some of the answers of the interviewees, it is notable that they suggest that the monastery has long been faced with certain problems of maintenance and repair of the dormitories. An elderly resident of Berovo in his face to face interview said that the monastery had to pay a special attention to the protection of the cultural heritage. The state, as well as the distinguished representatives of the Macedonian Orthodox Church - Ohrid Archbishopric should put more effort in order to take care of this monastery and to preserve it for the future generations. He holds that part of the financial problems can be solved with a planned development of monastery tourism.

\subsection{In which way were the nuns in the monastery recruited in the past, compared to nowadays?}

In the past, stepping into monasticism happened after a certain tragedy in the family, after a girl or woman had a dream or a special wish. At the beginning of the twentieth century, the monastery was a grand community and recruiting was far easier. During the period of communism, the number of nuns dramatically decreased. The revival of the monastic life in Macedonia, in general, echoed in the monastic sisterhood of this monastery.

An elderly female resident of Berovo told us about her close relative who became a nun. She was a child, when together with her older close cousin she entered the monastery for the first time and she shared this experience: "My cousin was fascinated with the 
monastery and just after one visit to the monastery she decided to become a nun." She only waited for the convenient moment to become a nun.

The abbess of the monastery describes the process of the recruitment of new nuns as follows:

Coming to a monastery is a voluntary act, and there is no way of recruiting monks The monasteries are open to all those who wish to spend their life devoted to God. There are no recruiting systems. What is important is that there is a period of novitiate which anyone who wants to be a monk must go through. This period is determined by the spiritual father who observes the whole process and spiritual growth of the novice. All the events in the monastery, whether positive or negative, are to be accepted with a prayer and thankfulness. That is why is important the honest and open relationship between the monk and his spiritual father, who at any moment is a spiritual support to the brotherhood or sisterhood.

In the interviews conducted with the nuns at the monastery of St. Archangel Michael, one of them wrote: "I joined the monastery 3 years ago, under obedience of the competent Bishop of the diocese. The process of novitiate, becoming a monk, as well as the communication with the outer world is a part of the life which the monk shares only with his spiritual leader." The role of the spiritual father is of critical importance, especially for the life of the female novices. A novice stated that she joined the monastery two years ago "in obedience to the Bishop of the diocese."

\subsection{Do they communicate with the nuns from other monasteries (in or outside Macedonia)? Do they interact with the nuns from Bulgaria, especially those who are near Berovo (near the border line)?}

Despite the fact that the monastery is located on the border with Bulgaria, the interviewees in their answers did not mention any cooperation with the Orthodox sisterhoods from this country. The nuns and novices also mentioned in their interviews that this type of communication is within the competences of the abbess of the monastery. As a response she said to us that she maintained communication with the nuns from other monasteries. ${ }^{29}$ But still it is not intensive communication, because life in every monastery takes place under a certain typikon and the nuns in all of those neighboring monasteries have their duties and are charged with activities which they must accomplished, so it is supposable that there is simply not enough time for such kind of activities.

In the secondary database it is stated that although the MOC-OA is not recognized by the orthodox churches throughout the world, the nuns of this monastery have frequent communication with the nuns who are not from their immediate vicinity, but from Romania and Greece.

The communication with other nuns is religious and invisible. It is performed at a spiritual level, in my heart; we are all one herd under our spiritual father who helps us to reach the Kingdom of Heaven while we are still on the Earth. Our prayers are devoted to the whole world, from down until dusk, for all humans in the world.

\footnotetext{
${ }^{29}$ Regarding communication with other nuns, one novice in her e-interview said: "Communication with other nuns is religious and invisible. It is performed at a spiritual level, in my heart; we are all one herd of our spiritual father who helps us to reach the Kingdom of Heaven while we are still on the Earth. Our prayers are devoted to the whole world, from down until dusk, for all humans in the world“.
} 


\section{INSTEAD OF A CONCLUSION: EMPHASIZING ONLY SOME ELEMENTS}

Based on the analysis of the collected empirical material (primary and secondary database) we offer the conclusion that the monastery St. Archangel Michael is a pillar of identity of the Maleshevo region.

Life in the monastery sisterhood has taken place continuously more than 150 years. But communication with other monastic sisterhoods, especially on the border with Bulgaria, almost does not exist.

\section{REFERENCES}

Andreevski, Petre M. (), Faithless Years: Records, Statements and Story Tales. Skopje: Makedonska kniga, 1974. Angelovska-Panova, M. "Monasticism in the Spiritual - Historical Continuity of Macedonia." Spektar XXIX, 57 (2011).

Bryman, A. Social Research Methods. Oxford: Oxford University Press, 2012

Cacanoska, R. Public Religion in Macedonia. Skopje: Law University, 2010.

Contributions from the scientific convention with international participation held on 06 and 07 May 2000 in Berovo, The Voivode Iljo Markov - Maleshevski and his time, Berovo, 2002.

Grozdanov, C. Archeological Map of the Republic of Macedonia, volume 2. Skopje: MANU, Republic of Macedonia, 1996.

Pachemska Petreska, D. Maleshevo Region through the History 1912-1945, volume 2. Berovo, 2003.

Teoharov N. A. Records and Inscriptions in the Churches in Maleshevo and Pijanec. Berovo: Studentski zbor, 2004.

Trajanovski, A. Dimitar Pop Georgiev-Berovski (1840-1907). Shtip: Society for Science and Arts, 1990.

Trajanovski, A. Church - Educational Municipalities in Macedonia. Skopje: Institute of National History, 1988.

\section{ŽENSKO MONAŠTVO U POGRANIČNOM PODRUČJU (Manastir Sveti Arhangel Mihael - Berovo)}

Predmet ovoga rada je prikaz ključnih momenata o osnivanju i životu u ženskom manastiru pri crkvi Sv. Arhangela, u Berovu. Ženski monaški život u ovom manastiru se odvija više od jednog $i$ po veka. U njemu, pored berovske loze monahinja, na službu dolaze i monahinje iz manastira Veljusa. Manastir u Berovu je otvorenog tipa. U manastiru može da se koristi i biblioteka, u kojoj se čuva uspomena na prosvetiteljski rad Joakima Krčovskog, osnivača prve ćelijske škole. Život u ovom manastiru odvija se prema isihastičkom tipihu (svetogorski) i pored toga što ima urbanu lokaciju $i$ što je dosta posećen. Manastir funkcioniše kao svešteno tihovalište, isihastirion. $U$ unutrašnjosti same crkve napravljen je mali paraklis posvećen Sv. Grigoriju Palami i Starcu Josifu Isihasti. Svakog dana se u manastiru održavaju službe i liturgije. Manastirom rukovodi igumenija. Njegovo funkcionisanje se odvija prema zaduženjima, koja se zovu poslušanija. Za ovaj manastir je specifično što se, pored pripreme tradicionalnih prehrambenih produkata iz ovog kraja, izrađuju i mozaici. I pored toga što Makedonska pravoslavna crkva-Ohridska Arhiepiskopije nije priznata od svetskih pravoslavnih crkvi, monahinje iz ovog manastira češće kontaktiraju sa monahinjama iz Rumunije i Grčke, nego sa onima iz neposrednog pograničja.

Ključne reči: manastir, žensko monaštvo, pograničje, tipih, verski turizam. 